\title{
Everyday Suffering and the Abstract Time-Reckoning of Law
}

\section{Reflections on the Allocation of Responsibility for an Asbestos Disaster in Italy}

\author{
David Loher
}

\begin{abstract}
How does time structure the allocation of responsibility in the context of large-scale corporate crimes? Focusing on the Processo Eternita criminal case brought against the former main investor in Europe's largest asbestos-processing factory in Casale Monferrato (Italy) - this article compares the temporal order of the lived experience of the asbestos disaster in the affected community with the abstract time-reckoning of law. The everyday suffering in the form of the long-term health effects, inscribed in the body through the asbestos fibre, collides with the statute of limitation of the alleged crimes, as stipulated in law and endorsed in the court room. It examines how these incommensurable temporalities reconfigure the allocation of moral and legal responsibility for an industrial disaster and shows how these contradictions are related to the victims' expectations of justice and their experience of injustice.
\end{abstract}

Keywords: asbestos, corporate crime, corporate responsibility, global value chains, industrial disaster, Italy, law, temporality

It is a strange location for a park. At the western end of the town, a narrow green area stretches between the arterial road and an old industrial ditch. In the middle of the small semi-abandoned industrial zone, Parco Eternot was built on the former factory site of the asbestosprocessing company Eternit S.p.A. The park's name is a reference to the industrial past of this place. ${ }^{1}$ Following the reclamation of the site, which had been contaminated with asbestos, the park now memorializes the workers and citizens who were the victims of asbestos production over the years. Until today, asbestos production caused more than two thousand deaths in Casale Monferrato, a small industrial town of merely thirty thousand inhabitants on the banks of the River Po, 
midway between Milan and Turin. Virtually every family is affected by this industrial disaster.

Under a solitary tree near the former director's building, the trade unions commemorate their deceased fellow workers with a metal plaque, decorated with a wreath of dried flowers. Yet the strangest reminder of this place's history is near the playground where a bed of runner beans, framed by turquoise painted wooden borders can be found. On it is written a poem in white letters: I fazoletti instrisi delle nostre lacrime metteranno le ali e voleranno lontano per sviluppare profondi radici di giustizia (Handkerchiefs, drenched in our tears, swing up high into the air; fly far away to develop deep roots of justice). The poem is a reference to the everyday experience of suffering and death - and to the subsequent and so far unsuccessful legal struggles 'to obtain justice', as the president of the victim's association AFeVA (Associazioni Famigliari Vittime Amianto) phrased it in her inauguration speech at the International Day for Asbestos Victims in April 2018 in the municipal theatre. The asbestos fibre killed not only factory workers but also ordinary citizens who never set foot in the building; people like the bank employee who passed the factory site on his daily run and who suddenly died of mesothelioma ${ }^{2}$ in his early thirties, or the baker from the nearby bakery who used to sweep the floor after the workers bought their lunch in their dust-covered boiler suits, spreading the deadly fibre wherever they went. In short, Casale Monferrato has been experiencing the effects of a 'harm industry' (Benson and Kirsch 2010) in a deep and existential way.

The ambivalent term 'justice' is at the centre of the argument of this article. In its colloquial use in the context of the anti-asbestos struggles in Casale Monferrato, the term carries ideas of responsibility for the industrial disaster and expectations of how the judiciary ought to enforce this responsibility. In the everyday language of the victims, justice refers to the expectation of attribution of personal criminal liability. Justice is thus conceived of as individual, and it is juxtaposed against various forms of compensation: voluntary compensation schemes, outof-court settlements, or compensation payments in the context of tort cases under civil law. This article explores how colloquial notions of responsibility and expectations of justice are related to each other. ${ }^{3}$ It focuses on one particular aspect that shapes such ideas of responsibility: time. The empirical point of departure is the Processo Eternit. This is a criminal case against the former main shareholder of the asbestosproducing factory in Casale Monferrato, accused of wilfully causing an industrial disaster resulting in multiple fatalities. ${ }^{4}$ After the convic- 
tion and sentencing to sixteen years of imprisonment of the accused by the court of first instance in 2012, two years later, the Italian Supreme Court vacated the sentence due to the statute of limitations of the alleged crimes. This acquittal led to mass protests by the victims and the broader public.

In this context, this article addresses three interrelated issues. First, it asks how the perception and experience of time shapes the allocation of moral responsibility. Second, it explores the contradictions between these ideas of moral responsibility and the allocation of legal responsibility in the trial. This allows us to examine how incommensurable temporalities connect and disconnect the allocation of moral and legal responsibility. And finally, it shows how these contradictions are related to expectations of justice and injustice.

The contradictions between moral and legal allocation of responsibility brings to the forefront an irresolvable tension between the available legal instruments, which are very limited in their capacity to deal with industrial harm produced by a transnationally organized industry on the one side, and the moral expectation of responsibility for transnationally produced but locally experienced harm (Eckert and Knöpfel this issue) on the other. ${ }^{5}$ While moral responsibility can simultaneously address the structural causes of harm production and single out individual responsibility within a transnational network of mutual responsibility shaped by global value chains, legal instruments - especially with regard to criminal law - are much more constrained. By its nature, criminal law tends to individualize responsibility and ignore structural aspects.

Based on ethnographic observation on the occasion of the International Day for Asbestos Victims in Casale Monferrato, the article starts with a reflection on the concept of responsibility and connects it to the notion of causation, following James Laidlaw's (2013) remarks in his discussion on agency and responsibility. It argues that notions of responsibility - legal and moral - hinge on ideas of causation that contain a spatial, temporal, and social dimension. The second part provides an overview of the global asbestos industry and the history of asbestos production in Casale Monferrato, with a particular focus on the legal struggles in the context of the Processo Eternit. The third part returns to the article's main question of the temporal dimension in the allocation of responsibility. It focuses on the final acquittal in the Processo Eternit and the public reactions to this acquittal as a means of exploring the relationship between time and responsibility. Here, the concept of time maps (Gell 1992) are used to explore the contradictions between 
individual suffering, collective experience, and the temporality of law. Finally, this article discusses how temporality shapes the perception of justice and injustice in the allocation of responsibility.

\section{Temporal and normative dimensions in the allocation of responsibility}

Every year in April, Casale Monferrato celebrates the Giornata internazionale delle vittime dell'Amianto (International Day for Asbestos Victims). It always follows the same template, and when I attended the meeting the last time in 2018, it was no different. The day started with a gathering in the town's beautiful Renaissance-era theatre. The rows of spectators were draped with the Italian tricolour with the words Eternit Giustizia (Eternit, Justice) in bold black letters; the emblem of AFeVA. Wherever there is an event of the AFeVA, you can be sure to see the tricolour with the main claim somewhere. After the opening words by local politicians and a musical intervention by pupils, the AFeVA president took the stage and addressed the audience. She looked back at the Processo Eternit that ended with the acquittal of the former main shareholder three years ago and deplored the denial of justice for the community. 'But we continue our fight', she added to the applause of the audience. She finished her talk inviting the audience to attend the following commemoration ceremony in the Parco Eternot.

Under a clear spring sky, a crowd of about fifty people gathered around the metal plaque that pays tribute to the deceased fellow workers. A former trade union leader gave a few words of introduction and recalled the history of the anti-asbestos struggle that began in the late 1960s in the factory at exactly this place. After that, former colleagues, anti-asbestos activists, and citizens lined up to lay down a flower and sprinkle the plaque with holy water. People hugged each other and exchanged a few words in hushed voices.

The day concluded with a mass celebrated in the nearby church in the afternoon. During the service, the priest called out the names of the fellow citizens who died last year of an asbestos-related disease. Towards the end of the ceremony, a man and a woman stood up and addressed the audience. They both had been diagnosed with mesothelioma only recently. Although everyone in the church knew of similar stories only all too well, the congregation attentively listened to their respective testimonies in a sincere and concentrated atmosphere. A man in his sixties recalled the moment when his family doctor dis- 
covered 'a shadow' on his lungs during a routine health examination. He described his feelings of angst and uncertainty in the following days until the doctor confirmed the diagnosis. 'Now it's got me too', he said as concluded his testimony. He sat down and a moment of silence followed.

This vignette of the Asbestos Victims' Day brings together in condensed form the different strands that shape ideas of justice and responsibility in the context of the asbestos disaster. Personal experience is intertwined with collective memories and the bitter conviction that justice had been denied to the community. While the suffering continues in town with the regular announcement of further asbestos victims, the accused defendant got acquitted by the judiciary because too much time had passed since the offences occurred. However, two issues complicate any simplistic attempt to answer the critical questions of who is responsible and on which grounds for the asbestos disaster. First, the principles for the allocation of responsibility are highly contested. In particular, the judiciary follows principles and logics different from asbestos victims in their respective reasoning about the allocation of responsibility. And second, with regard to the specific case of the asbestos disaster, time is a decisive factor. Therefore, a theoretical framework is required that captures these two aspects of the allocation of responsibility.

Broadly speaking, responsibility is the attribution of obligation for the consequences of actions. ${ }^{6}$ This definition contains a reference to the normative aspect of responsibility, as the attribution of obligations hinges on an implicit or explicit normative frame of reference, and it refers to the relational aspect of responsibility in its emphasis of a connection between action and consequences. This relational aspect of responsibility relies on the idea of a constructivist reading of the idea of causation that cannot be dissociated from the normative question (see Laidlaw 2013). It includes three intertwined dimensions; social, spatial, and temporal.

Julia Eckert (2016) refers to the social dimension through the notion of communities of responsibility (Verantwortungsgemeinschaften). This term indicates that the allocation of responsibility creates bonds between those who are affected - usually negatively - by the effects of actions and those who originated those actions. It rejects the idea that relationships of responsibility necessarily rely on pre-existing and tightly knit communities of solidarity, which are typically conceived of in terms of shared identities such as nations (including multicultural nations), ethnic or kinship groups (e.g. Banting and Kymlicka 2017). 
Under the conditions of world society, the spatial dimension of responsibility is particularly salient in the context of corporate crimes. The increasing importance and density of global value chains (see Gibbon et al. 2008) have put the question of the reach of corporate responsibility high on the political agenda.

Yet beyond this spatial extension, the relational aspect of responsibility further contains a temporal extension. Actions in the past have effects in the present and the future and are connected through the allocation of responsibility. Notions of responsibility mediate the past, the present, and the future. Relying on Alfred Gell's (1992) three ideal types of time and his concept of time maps as a means to navigate time, this article develops an interpretation of the contradictions between the temporality enshrined in law and the personal and social experience of time in the everyday.

This article combines the temporal aspect in the allocation of responsibility for corporate crimes with the normative aspect, which is the second key aspect in the definition of responsibility. The normative aspect has been extensively discussed in the context of research on corporate social responsibility (e.g. Dolan and Rajak 2011, 2016; Foster 2010; Garsten 2010; Kirsch 2014; Welker 2014). What these contributions have in common is that they consider corporations' embrace of the language of responsibility as 'a theatre of virtue' (Rajak 2011) deployed by corporations to escape 'proper' - that is legal - responsibility. The anthropology of corporate social responsibility (CSR) sheds light on the fact that the normative point of reference for the allocation of responsibility is a matter of contestation. In this article, I complete the CSR discussion with an approach that explores the issue of the normative aspect of responsibility in relation to criminal law. As soft law, CSR frameworks reflect vague notions of responsibility. In their extreme version, they operate as mere 'empty signifiers' (Laclau 2007: 232). In contrast, responsibility reified in the form of hard law - either criminal or civil law - provides much stronger and clear-cut regulations. Hard law forces decisions, while soft law establishes flexible and blurred boundaries that operate with 'non-binding coercion' (Zerilli 2010: 5).

Before discussing the allocation of responsibility in its temporal inscription with regard to the ethnographic data, the following section provides a brief overview of the asbestos industry and the material properties of asbestos fibre in order to demonstrate the importance of the temporal dimension of the asbestos disaster. 


\section{Dirty old town: Asbestos production in Casale Monferrato}

Asbestos is a naturally occurring silicate mineral compound composed of long microscopic fibres. Cheap, abundantly available, fire-proof, acidresistant, and light, it became the emblematic material of the post-World War II economic expansion. Robert L. Virta's (2006) calculations for the US Geological Survey show how the demand exploded after 1945. In only ten years, global consumption doubled, peaking in 1980 with an annual consumption of almost five million tonnes. In Europe, with the exception of the Soviet Union, Italy was the largest producer of asbestos from 1940, thanks, in particular, to the large asbestos mine at Balangero in the Piedmontian alps (see Biagioni 2006). Italy was also among the main consumers of asbestos in Europe.

The factory in Casale Monferrato was a supplier for the construction industry, where the product was used in the form of fibre cement. This processing method was invented by the Austrian Ludwig Hatschecke and marketed under the brand name Eternit, which quickly became a synonym for fibre cement. All over the world, a conglomerate of companies emerged that all used the brand name Eternit to market their asbestos-cement products. In Italy, it was the engineer Alfredo Mazza who founded Eternit Italia in 1906 and established the asbestos-processing facility at Casale Monferrato (Ziglioli 2016: 28). It became the largest asbestos factory in Europe. For decades, it was an important employer in the region, providing stable and well-paid jobs with generous additional benefits (Ziglioli 2016: 37). In its heyday, the factory employed over eight thousand workers, which made it the largest employer in the region, attracting workers from both the town and the nearby countryside. The situation gradually changed starting in the 1970s, when the construction industry was hit by the economic crisis. The factory faced several rounds of restructuring. The number of employees declined over the years, and when the factory went bankrupt in 1986, fewer than four hundred workers remained on its payroll (Ziglioli 2016: 71). In addition to the economic crisis, the Eternit factory came under increasing pressure due to rising concerns about the hazardous nature of asbestos fibre. Since the 1960s, scientists have warned the public about the health risks of asbestos. The work of the medical researcher Irving Selikoff, in particular, clearly highlighted the correlation between certain diseases and asbestos exposure (Castleman 1996: 159-161; McCulloch and Tweedale 2008). However, these insights had little impact on safety-at-work measures in the factory, as former workers remembered in several private conversations and also testified 
publicly in the court room during the Processo Eternit; the workshops in the factory were characterized by a dusty work environment and a lack of protective measures such as air filters. ${ }^{7}$

In the case of Casale Monferrato, the asbestos-related health problems did not remain behind the factory gates. From the late 1970s, more and more ordinary citizens were affected by diseases caused by asbestos exposure (see Ziglioli 2016: 67). In contrast to the workers, who mostly suffered from asbestosis - a disease caused by exposure to large quantities of asbestos fibre - the urban residents were affected by mesothelioma, a form of pleural cancer caused by low exposure to asbestos and with incredible long latency periods of three to four decades.

The heavy toll Casale Monferrato has been paying for the pollution of the environment over decades raised the question of responsibility and compensation at various levels. In the beginning, it was exclusively framed as an issue of worker's compensation schemes (see Boggio 2013) and mainly involved the national industrial injury insurance INAIL (Istituto nazionale per l'assicurazione contro gli infortuni sul lavoro). Workers struggled for inclusion in compensation schemes that provided higher benefits due to the particular dangers of this workplace. One of the most important trials in this respect was held in 1983. Yet these compensation schemes excluded by their nature all the residents of the town who were affected by asbestos-related diseases but had never worked in the Eternit factory.

In recent decades, the issue of compensation for asbestos-related diseases has occupied the courts in many industrialized countries that were formerly important asbestos producers, yet most of these litigation cases were negotiated under private law. In the United States and the United Kingdom, in particular, asbestos litigation has a distinct history. Asbestos litigation is responsible for the largest mass tort in US legal history (White 2006 and has developed its own dynamics. The pursuit of compensation for asbestos injuries has brought down entire corporations. For example, Johns-Manville Corporation, one of the largest asbestos manufacturers worldwide, filed for bankruptcy when faced with the threat of a mass tort litigation claim in 1982. In the United Kingdom, one of the largest asbestos manufacturers, Turner \& Newall, went bankrupt due to mass tort litigation claims (Tweedale and Hansen 2000). For US lawyers, asbestos litigation has become a highly profitable business (Carrington 2007).

In Italy, however, the situation is different. In general, asbestosrelated cases were filed under criminal law (Boggio 2013). This is related to the different legal traditions of civil law countries, where the 
question is less centred on compensation and focuses more on fault and punishment. In the context of such criminal trials, the victims usually claim compensation as civil joint plaintiffs. This was the case in the Processo Eternit, which is the focus of the following section.

\section{Negotiating responsibility for an industrial disaster}

The struggles around asbestos production in Casale Monferrato can be described as a steady 'juridification of protest' (Eckert et al. 2012) since the 1980s. ${ }^{8}$ What began as a labour struggle for better working conditions and adequate safety-at-work measures has turned into a more general legal battle for the recognition of the environmental disaster caused by decades of asbestos production in immediate proximity to the city centre. Several factors have conjoined in this development. Although it is impossible to identify an exhaustive list, two aspects have been critical to this transformation of the social struggle into a legal struggle as the workplace, the streets, trade union offices, and the circoli (workers' clubs), which were the main sites of the workers' struggle, have given way to lawyers, judges, and courtrooms. First, asbestos-related diseases have affected workers and the ordinary citizen population alike. Since its early days, the Eternit factory was notorious for the hazardous working environment. Labourers were well aware that they were putting their health at risk at this hazardous workplace. In an interview, a former employee remembered entering the factory as a young adult on his first working day. An older fellow worker welcomed him and warned him that it was a pity he was risking his health at such a young age working in this hazardous environment. ${ }^{9}$ Yet it was rare for workers to openly voice such concerns in the 1960s, as two former trade union leaders confirm in their interviews. ${ }^{10}$ Andrea Sangiovanni (2014) shows a similar phenomenon in his study on the representation of the Italian working class. The masculine-dominated working-class consciousness did not allow the open discussion of health issues. The undisputed ideal was the strong and able-bodied male worker and not the vulnerable and injured body. For this reason, labour struggles focused on job security and salaries rather than health issues and safety-at-work measures. This slowly changed, when it became obvious that the problems were not contained behind the factory walls and an increasing number of ordinary citizens were suffering from asbestos-related diseases. What had once been a class issue that exclusively concerned the working class all of a sudden threatened the whole population. Or, to put it in the 
language of Ulrich Beck; the asbestos fibre escaping the factory resulted in a democratization of risk (Beck 1996: 39-41).

The second aspect that can be identified as contributing to the transformation of the social struggle is the emerging environmental movements of the 1970s (see Barca 2011, 2014). This contributed to a growing awareness of the environmental damage caused by the production of asbestos. The large number of affected people who were not employed in the industry raised new legal issues. The various public compensation schemes for asbestos diseases were limited to (former) Eternit workers, while other citizens who had not been employed by the company were excluded.

The transformation of a labour struggle into a wider social movement is also reflected in the legal struggles. Three exemplary court cases show this transformation. They were the subject of significant public discussion. In 1983, workers contested the decision in court of the INAIL to exclude them from a compensation scheme called rendita di passagio. ${ }^{11}$ In contrast, in 1993 the local management was in the dock, accused of ignoring safety-at-work measures. Sentenced by the court of first instance, they were later acquitted by a higher instance. Yet the legal struggles around asbestos production in Casale Monferrato culminated in the Processo Eternit. This trial started in 2009, twenty years after the closure of the factory. The public prosecutor accused the two former main investors of wilfully causing an environmental disaster with multiple deaths, according to articles 437 and 434 of the Italian penal code. With 2,191 deaths and 665 cases of personal injury, it was one of the largest ever criminal cases against the top management of a transnational company (Altopiedi 2013; Coggiola and Graziadei 2014). In February 2012, the court of first instance sentenced the two accused to sixteen years imprisonment and to make compensation payments of 90 million euros. This sentence received much public attention, not only in Italy. Thousands of anti-asbestos activists and trade union members from all over Europe gathered before the courthouse in Turin to hear the verdict. Not surprisingly, the defendants immediately appealed the sentence. A year later, in the Court of Appeals, the judges not only confirmed the conviction, they even increased the punishment against the one defendant who remained - the other having died shortly before the judgement was delivered - to eighteen years imprisonment. Yet the Supreme Court vacated the sentence in December 2014 due to the period of prescription of the alleged crimes. Immediately after this final decision by the Supreme Court, the public prosecutor prepared a second indictment, this time on a charge of manslaughter. After a 
detour to clarify procedural questions - that is, statutes of limitations and a potential violation of the non bis in idem principle - the case is, as of late 2020 still pending in various district courts. ${ }^{12}$

The acquittal provoked a lively debate among the Italian public and was heavily criticised. Even former Italian Prime Minister Matteo Renzi expressed his discontent with the judgement in a radio interview: 'Either it is not a crime ... or it is one, but it is time-barred. And then we have to change the law', he commented on the acquittal in a radio interview..$^{13}$ The outcome of the Processo Eternit and the widely shared discontent with the final acquittal did indeed affect legislation, as the Italian parliament introduced a new article on environmental crimes (the legge eco-reati) into the penal code in remarkable short time, after the draft law had stalled for a long time somewhere between commissions and parliament the years before. ${ }^{14}$

But why did the Supreme Court's decision provoke such fierce criticism at all? The legal principle of limitation periods as such is not a contested issue. It is generally accepted and is acknowledged also by laypersons not trained in law as a central principle with the important function to guarantee legal certainty and predictability, though unsurprisingly, it might become an issue in certain contested court decisions. However, acquittals due to the prescription of alleged crimes is a frequent outcome in Italian jurisdiction and considered a symptom of the dysfunctional judiciary that offers lot of space for delaying court decisions. As such, it is the expression of a general and dormant mistrust in the legal system and the widely shared conviction that it protects the powerful who can afford lengthy - and therefore costly - legal disputes.

The diffuse mistrust in state institutions and the political establishment has a long history in Italian politics, yet it reached a new dimension precisely at the time of the trial. It coincides with the rise of the populist Five Star Movement (Movimento Cinque Stelle, M5S), founded in 2009 by the well-known comedian Beppe Grillo and the businessman Gianroberto Casaleggio (Tronconi 2015). With its antiestablishment, anti-immigration, and environmentalist programme, it gathered a heterogeneous electorate of disappointed citizens across the whole political spectrum from the right to the left. However, the anti-asbestos movement has a radically different political orientation. It has strong roots in the trade union movement and its critique of the judiciary is much more nuanced and does not result in the rejection of state institutions. 


\section{Responsibility and incommensurable time maps}

Beyond the specific historical and political context that shaped the debates on responsibility and the acquittal in the Processo Eternit, the following section suggests reading the rejection of the final acquittal as an effect of the incommensurable temporalities inscribed in the law and in the lived experience of the asbestos disaster in Casale Monferrato. This incommensurability leads to the conviction 'that we were denied justice', to quote the AFeVA president at the 2018 International Day for Asbestos Victims. In contrast to the court decision that acquitted the accused defendant and declared the alleged crime as time-barred, the everyday experience in Casale Monferrato is that asbestos is not a chapter from a far past that can be closed. Gell's (1992) concept of time maps offers a productive starting point to capture the incommensurable temporalities. He starts with the distinction of three ideal types of time. The first is non-human space-time, which is beyond human perception in its pure form. It refers to the ontological dimension of time (see Hein 2013)..$^{15}$ The second ideal type is the personal experience of time. Gell identifies the social framing of time as the third ideal type (see also Bear 2014: 15-16). Ignoring its ontological dimension, I focus on the various articulations of social time (see Greenhouse 1989) and explore their relationship to the personal experience of time.

In order to navigate time, human beings rely on time maps. They encapsulate temporality and are socially constructed representations of time (Gell 1992: 240). Contradictory time maps inscribed in law and in the collectively and individually lived experience of the asbestos disaster result in incommensurable ideas of how to allocate responsibility for the disaster. Yet these temporal orders do not have equal defining power, and it is rather a competition over the hegemonic temporal order than a coevalness in the making (see Birth 2008). Munn recalls that the control over time is 'a medium of hierarchic power and control' (Munn 1992: 109). The time map enshrined in law trumps the vernacular time map drawn by the asbestos fibre and experienced by the local community. The vignette of the International Day for Asbestos Victims shows how personal experience of time and the collective framing of time in the community reveal a temporal logic of an unfinished past. The testimony during the church service by the older man recently diagnosed with mesothelioma highlights how the past is haunting the present. The image of the 'shadow on the lung' - obviously a reference to how mesothelioma appears on the X-ray - is at the same time also a symbol how the past casts a shadow over the present in everyday life. 'Here in 
Casale, we live with the doubt. You never know, whether it will hit you too', one of the main figures of the anti-asbestos struggle explained to me, when he drove me around in town to show me the major sites of the asbestos era. ${ }^{16}$ I frequently encountered similar descriptions during my research. La paura è ovunque (fear is everywhere) was how one former factory worker described the feeling of uncertainty. ${ }^{17}$ The impossibility of diagnosing mesothelioma before its outbreak underlines this uncertainty, and no one who had been living in the region prior to the closure of the factory knows for sure whether he or she will be affected by the disease. This uncertainty is an element that stretches the disaster out in time. In other words, with regard to lived experience, the industrial disaster has not come to a halt. It turned out that the bankruptcy of the corporation and the cessation of the economic activities was not the final chapter of the history of asbestos in Casale Monferrato. Rather it has become a persistent incident, refreshed once more with every new asbestos-related death that occurs in the community.

\section{The hegemonic temporal order of law}

The asbestos victims' time maps and the hegemonic time map authorised and sanctioned by law operate in different way. The focus on the allocation of responsibility allows for exploring these differences in greater detail. In the process of connecting time and law, the allocation of responsibility is one important mode of operation how law establishes a temporal order. It describes a connection between an event defined in time and an effect that is time-dependent from this event, mediated by an instance singled out as the cause of the event. Thus, it establishes a precise and immutable temporal order and connects this order to an actor. This generation of a temporal order through the allocation of responsibility is similar to evidence production. In this context, Keebet von Benda-Beckman argues that evidence production is a procedure for how a hegemonic temporal order is established that generates 'authorised knowledge and truth' (2014: 6).

The Processo Eternit shows that the allocation of responsibility through law has no vocabulary to capture the unfinished past experienced by the asbestos. Law and experience rely on contradictory temporal orientations; a progressive temporal orientation in law, and a regressive temporal orientation by the asbestos victims.

The critical element for law's progressive temporal orientation in the Processo Eternit is the statute of limitations, a legal principle that 
defines the maximum time after an incident within which legal action may be taken. As the contradictory judgements of the court of first instance and the Supreme Court show, it is difficult to identify the relevant moment in time for an ongoing incident such as the silently unfolding and continuing asbestos disaster that has unpredictable longterm effects. But no matter how contested the definition of this relevant moment in time is, it sets the temporal zero from where any calculation starts. The statute of limitation then defines how much of the following time period has to be taken into account.

In its judgement from 2014, the Supreme Court's deliberation focused on the critical question of the moment in time at which the alleged crime was completed..$^{18}$ Did the cessation of the company's economic activities imply the end of the alleged criminal act? Or was it only completed with the death of the asbestos victims? The Supreme Court eventually decided that the alleged criminal act was completed with the bankruptcy of the corporation in 1986. This means that the period of limitation began at this specific moment in time. The Supreme Court therefore concluded that the alleged crimes according to Article 437 $\mathrm{CP}$ and Article $434 \mathrm{CP}$ were time-barred and acquitted the defendant.

This detail was critical, as the whole trial focused on the intentional causation of an industrial disaster due to the public prosecutor's choice to file the accusation under Article $437 \mathrm{CP}$ and Article $434 \mathrm{CP}$ of the Italian Penal Code. Article $437 \mathrm{CP}$ sanctions the 'removal or malicious omission of precautions against accidents at work'.19 Article $434 \mathrm{CP}$ sanctions the causation of the 'collapse of buildings or other intentionally caused disasters' ${ }^{20}$ Colloquially expressed, the fatalities were 'only' the unfortunate consequence of the intentional causation of the asbestos disaster. Contrary to public awareness, the legal focus was on the causation of the disaster and less on the fatalities as a consequence. Typically, in cases of deaths or personal injuries resulting from poor working conditions, the indictment against the employer is often manslaughter (omicidio colposo) according to Article $589 \mathrm{CP}$ or negligent personal injuries (lesioni personali colpose) according to Article 590 CP (Coggiola and Graziadei 2014: 31). The public prosecutor chose a different approach in the Processo Eternit due to the extraordinarily high number of victims and claimants and in light of the fact that charges based on Art $437 \mathrm{CP}$ and Article $434 \mathrm{CP}$ are easier to substantiate.

This detailed deliberation of the critical incident for the calculation of the period of limitation as an expression of the future-binding force of law (see Kirste 2002; Luhmann 1981) contributes to a reliable and predictable judiciary, though the temporal order imposed by the 
Supreme Court erases the long-term effects of the industrial disaster from the broader picture. These effects consist mainly of two elements. Firstly, the pollution of the environment did not stop with the cessation of the company's economic activity. Piles of asbestos waste remained on the abandoned factory site, and it took the municipality years to rehabilitate the contaminated area. This also included additional sites, such as the riverbed where the factory's waste-water outlet discharged polluted water into the River Po. And second, with regard to the long latency period of certain asbestos-related diseases, the Supreme Court's decision separated the casualties from the asbestos disaster. Even if the public prosecutor had brought the case to the court within the relevant timeframe dictated by the statute of limitations in accordance with the Supreme Court's deliberation, hundreds of potential future victims would have been ignored - not only as possible civil joint plaintiffs but also as part of the criminal indictment. Taken together, the narrowing of the temporal focus with the exclusion of the long-term effects results in a limited partial picture of the harm caused by the asbestos disaster.

All too short periods of prescription are a recurrent issue in the context of asbestos litigation, as they deny potential victims access to justice. This is a problem that has already been identified in other court cases and not only in Italy. For example, in Howald Moor and Others v. Switzerland (Application Nos. 52067/10 and 41072/11), the European Court of Human Rights (ECHR) ruled in a landmark decision in 2014 that the existing statute of limitations infringes the right of access to a court and to a fair trial of a person suffering from diseases that cannot be diagnosed until many years after the event. ${ }^{21}$

\section{Time and everyday experience}

Asbestos victims have a different time calculation in their allocation of responsibility, as their point zero is the outbreak of the disease. From this moment, they look back in time to identify the cause for their disease in order to allocate responsibility. Their temporal order is thus regressive. The statute of limitations does not correspond with the latency periods of certain asbestos diseases and thus creates inextricable contradictions between law and the lived experience of the industrial disaster. In contrast to the Supreme Court's reasoning, the closure and bankruptcy of the factory is of little importance for the asbestos victims. What counts for them is the fact that the disaster continues to claim its toll in the present day. For the most affected region of Casale 
Monferrato, CPO Piemonte records around fifty cases per year. ${ }^{22}$ Obituaries in the local newspaper regularly mention asbestos as the cause of death. And there is an omnipresent uncertainty as to whether one will be affected by mesothelioma in the future.

As the vignette of the International Day of Asbestos Victims shows, the past haunts the present, and with the enduring uncertainty and fear, it stretches the disaster even further into the future. The resulting time map of the asbestos victims is thus dominated by the hegemonic presence of the past.

This representation of time does not establish a fixed and stable temporal order between 'the before' and 'the after', but rather a relational order between past, present, and future. Gell distinguishes these two different categorizations of events in time-space as a dynamic and relational A-series of time and a static and fixed B-series of time (see Gell 1992: 151-152). Through the regressive temporal orientation of the asbestos victims, every new incident rearranges the temporal order and creates new connections between the past and the present.

This specific relational representation of time is reflected in the allocation of moral responsibility by the asbestos victims. It is expressed in the following quote by one of my interviewees, a former trade unionist. Referring to the accused, he told me in an interview: 'Lui ha fatto un sacco di soldi. E noi dovremmo pagarne il prezzo. Fino ad oggi!' (He made a fortune. And we should pay the price. Until today). ${ }^{23}$ In parallel to the expansive characteristics of the past in the case of the asbestos disaster, the victims' allocation of responsibility operates with a similar representation of time. The interviewee's statement further expresses a sharp contradiction between the former main investor, depicted as a profiteer from industrial asbestos production, and the local population, who are still paying the toll. It contains the idea that profits entail responsibility. This idea does not primarily hinge on action and omission as the conditions of the possibility for the allocation of responsibility but introduces an alternative line of argument. The connection between profits and responsibility for harm refers to global value chains - the flows of goods and capital - as a justification for the allocation of responsibility. It is ultimately a form of strict liability that assigns a special duty of care to those who extract the profits in this transnational network of relationships.

Yet the trial did not provide any conclusive evidence about whether the accused actually made these large profits as the victims claim. During the trial, the defence firmly rejected this proposition and repeatedly claimed that the factory in Casale Monferrato was never prof- 
itable from the time the accused became the main investor in the 1970s. Instead, the defence presented the defendant as a judicious entrepreneur, who did everything possible to exit asbestos production from the beginning and replace the hazardous material as soon as possible.

\section{Conclusion}

The discussion of the contradictions between the abstract time-reckoning of law and the concrete social experience of time in the context of the Processo Eternit brings us back full circle to the question of justice raised in the introduction. As Bhopal (see Cassels 1993) and other cases have demonstrated, it is a complex - and often futile - endeavour to allocate legal liability for large-scale industrial disasters in contemporary world society. All too often, the available legal instruments are impotent when confronted with the complex reality of global value chains and their complex chains of causes and effects. They may even be at the origin of the organization of irresponsibility, as Scott Veitch (2007) observes with regard to human rights. The boundaries of global value chains are blurred, and so are chains of responsibility. The analysis of the Processo Eternit has shown that law is not only limited in its ability to capture responsibility in its spatial extension, but also in its temporal dimension.

The statute of limitations curbs responsibility in time. The outcome of the Processo Eternit established a hegemonic temporal order that contradicts the existential experience of suffering, fear and loss of the asbestos victims, just as it negated the specific temporality of the asbestos fibre and the body's reaction to the substance. In this specific case, the statute of limitations is experienced as a means to organize irresponsibility. However, the potential of the law to render the future predictable does not necessarily imply its complicity with the abstract time-reckoning of capitalism and its hegemony over the time map of lived experience, as the discussion of the Processo Eternit might imply. We can think of alternative legal institutions containing a future-binding force that represent the experience of the asbestos disaster more adequately. The principle of strict liability is such a candidate - a legal principle we find in tort law rather than in criminal law (see Moore 1972).

The disruptive force of law's hegemonic time map surfaced during the 2018 International Day for Asbestos Victims throughout the whole day. The deep-rooted feeling of injustice, as voiced by the president in her inaugural talk, was more than the regret of a lost battle over an incident that took place decades ago. The testimonies of the daily 
suffering during the mass were the manifestation of the fact that the environmental disaster caused by the asbestos fibre is not something that occurred in a long ago past, as the decision of the court implies, but an incident that is still woven into everyday life in Casale Monferrato.

\section{Acknowledgements}

I am grateful for the critical reading of previous versions of this manuscript and the detailed comments by the two guest editors Julia Eckert and Laura Knöpfel. The text profited a lot from the comments of the two anonymous reviewers. Their critiques helped me sharpen my argument. I received further helpful feedback from the audience of the Tuesday Research Seminar at the Institute of Social Anthropology at the University of Bern, where I presented part of my argument in May 2020. The continuous exchange of thoughts and the discussions especially with Laura Affolter, Sharib Ali, Angela Lindt, Johanna Muggler, and Kiri Santer at our regular research colloquia is an inspiring source for new ideas. However, I am solely responsible for any remaining factual error or flaws in the argumentation.

David Loher PhD is a post-doctoral researcher and lecturer at the Institute of Social Anthropology, University of Bern (Switzerland). He is interested in questions at the intersections of law, state, and the economy. In his current research project on the hazardous legacy of the asbestos industry in Italy, he focuses on the allocation of responsibility in the context of corporate crimes. Email: david.loher@anthro.unibe.ch

\section{Notes}

1. The park's name is a pun. Replacing the ' $\mathrm{i}$ ' of the factory's name with an 'o' hides a 'no' in the name, which is a reference to the decades of protest against the factory.

2. Mesothelioma is a form of pleural cancer. Low doses of exposure to asbestos fibre are sufficient to cause this disease. It is characterized by extremely long latency periods of three to four decades.

3. The article draws on a range of sources and ethnographic material. It uses court documents and newspaper coverage of the trial and combines these with a series of interviews with key informants. The final source is participant observation of various public events, mainly organized by the AFeVa, which was carried out between 2017 and early 2020. 
4. Article 437 CP (Rimozione od omissione dolosa di cautele contro infortuni sul lavoro) and Article $434 \mathrm{CP}$ (Crollo di costruzioni o altri disastri dolosi) of the Italian Penal Code.

5. Kim Fortun (2001) examines how responsibility dissolves in transnational corporation structures in her ethnography on one of the biggest industrial disasters of modern time, the Bhopal disaster in India in 1984.

6. The term action also includes omission; in the context of corporate responsibility, omission is arguably the more important aspect.

7. Interview September 2017.

8. Julia Eckert et al. (2012) focus on social movements and their legal struggles 'against the state'. While in a trial in 1983 (see above), it was indeed 'the state' - or, more precisely, the Istituto nazionale per l'assicurazione contro gli infortuni sul lavoro INAIL - that was in the docks, the following legal struggles focused on the factory's top management and the investors.

9. Interview September 2017

10. Interviews September 2017

11. Decreto 30 giugno 1965, No 1124 (Gazzetta ufficiale No. 257, 13 October 1965).

12. Non bis in idem is the legal doctrine that no legal action shall be deployed twice for the same cause of action.

13. Radio interview with Matteo Renzi, RTL 102.520 November 2014.

14. Legge 20 maggio 2015 sulle eco-reati. This law was inserted into the Italian Penal Code under Art. 452-bis - Art. 452-terdecies.

15. For a detailed critique of time as an ontological property, see Ringel (2016).

16. Fieldnotes September 2017

17. Interview September 2017.

18. Sentenza Nr. 1292/ 2014, Corte Suprema di Cassazione.

19. Rimozione od omissione dolosa di cautele contro infortuni sul lavoro (Art $437 \mathrm{CP}$ ).

20. Crollo di costruzioni o altri disastri dolosi (Art $434 \mathrm{CP}$ ).

21. European Court of Human Rights (ECHR), 'Affaire Howald Moor et Autres C. Suisse', http://hudoc.echr.coe.int/eng?i=001-141567 (accessed 12 December 2019). See also the ECHR press release ECHR 069 (2014), 11 March 2014, https://hudoc.echr .coe.int/app/conversion/pdf/?library=ECHR\&id=003-4695490-5697809\&filename $=$ 003-4695490-5697809.pdf.

22. The latest available statistics refer to the period between 2012 and 2016. Statistics record 83 women and 133 men who were diagnosed with mesothelioma in this period. See CPO Piemonte Centro di Riferimento per l'Epidemiologia e la Prevenzione Oncologica in Piemonte, 'Pleural Malignant Mesothelioma, Piemont 1990-2016', https://www.cpo.it/workspace/files/2-pleural-mesothelioma-inciden -5ce2655fb72f0.pdf (last accessed 15 March 2020) See also the 6th INAIL report of the national mesothelioma register, https://www.inail.it/cs/internet/docs/alg-pubbl -registro-nazionale-mesoteliomi-6-rapporto.pdf (last accessed 21 November 2020)

23. Interview September 2017. 


\section{References}

Altopiedi, R. (2015), 'The Italian Eternit case', in J. van Erp, W. Huisman, and G. Vande Walle (eds), The Routledge Handbook of White-Collar and Corporate Crime in Europe (London: Routledge), 346-360.

Banting, K. and W. Kymlicka (2017), 'Introduction: The political sources of solidarity in diverse societies', in K. Banting and W. Kymlicka (eds), The Strains of Commitment: The Political Sources of Solidarity in Diverse Societies (Oxford: Oxford University Press), 1-60.

Barca, S. (2011), 'Bread and poison: Stories of labor environmentalism in Italy, 19681998', in C. Sellers and J. Melling (eds), Dangerous Trade: Histories of Industrial Hazard across a Globalizing World, (Philadelphia, PA: Temple University Press), 126-139.

Barca, S. (2014), 'Work, bodies, militancy: The "class ecology" debate in 1970s Italy', in S. Boudia and N. Jas (eds), Powerless Science?: Science and Politics in a Toxic World. (New York: Berghahn Books), 115-133.

Bear, L. (2014), 'Doubt, conflict, mediation: The anthropology of modern time', Journal of the Royal Anthropological Institute 20 no. S1: 3-30. doi:10.1111/1467-9655.12091.

Beck, U. (1996), Risk Society: Towards a New Modernity. (London: Sage).

Benda-Beckmann, K. von (2014), 'Trust and the temporalities of law', The Journal of Legal Pluralism and Unofficial Law 46, no. 1: 1-17. doi:10.1080/07329113.2014 .894743 .

Benson, P. and S. Kirsch (2010), 'Capitalism and the politics of resignation', Current Anthropology 51, no. 4: 459-486. doi:10.1086/653091.

Biagioni, E. (2006), Ci fermavamo sempre al bottegone: Cronaca della chiusura della più grande miniera di amianto in Europa (Turin: Bradipolibri).

Birth, Kevin (2008), 'The creation of coevalness and the danger of homochronism', Journal of the Royal Anthropological Institute 14, no. 1: 3-20. https://doi.org/ 10.1111/j.1467-9655.2007.00475.x.

Boggio, A. (2013), Compensating Asbestos Victims: Law and the Dark Side of Industrialization (Farnham: Ashgate).

Carrington, P. D. (2007), 'Asbestos lessons: The unattended consequences of asbestos litigation', Review of Litigation 26, no. 3: 584-611.

Cassels, J. (1993), The Uncertain Promise of Law: Lessons from Bhopal (Toronto: University of Toronto Press).

Castleman, B. I. (1996), Asbestos: Medical and Legal Aspects (Englewood Cliffs, NJ: Aspen Law \& Business).

Coggiola, N. and M. Graziadei (2014), 'The Italian “Eternit trial”: Litigating massive asbestos damage in a criminal court', in W. H van Boom and G. Wagner (eds), Mass Torts in Europe: Cases and Reflections (Berlin: de Gruyter), 23-45.

Dolan, C. and D. Rajak (2011) 'Introduction: Ethnographies of corporate ethicizing'. Focaal no. 60: 3-8. doi.org/10.3167/fcl.2011.600101.

Dolan, C. and D. Rajak (eds) (2016), The Anthropology of Corporate Social Responsibility. (New York: Berghahn Books).

Eckert, J. M., B. Donahoe, C. Strümpell, and Z. Ö. Biner (eds) (2012), Law against the State: Ethnographic Forays into Law's Transformations (Cambridge: Cambridge University Press). 
Eckert, J. (2016), 'Tugend, Recht und Moral: Tendenzen der Verantwortungszuschreibung', Deutsche Zeitschrift für Philosophie 64, no. 2: 246-257.

Eckert, J. and L. Knöpfel (2020), 'Legal responsibility in an entangled world,' this issue.

Fortun, K. (2001), Advocacy after Bhopal: Environmentalism, Disaster, New Global Orders (Chicago: University of Chicago Press).

Foster, R. J. (2010), 'Corporate oxymorons and the anthropology of corporations'. Dialectical Anthropology 34, no. 1: 95-102.

Garsten, C. (2010), 'Ethnography at the interface: 'Corporate social responsibility' as an anthropological field of inquiry'. In M. Melhuus, J. P. Mitchel and H. Wulff (eds) Ethnographic Practice in the Present. (New York: Berghahn Books).

Gell, A. (1992), The Anthropology of Time: Cultural Constructions of Temporal Maps and Images. (Oxford : Berg).

Gibbon, P., J. Bair, and S. Ponte (2008), 'Governing global value chains: An introduction', Economy and Society 37, no. 3: 315-338.

Greenhouse, C. J. (1989), 'Just in time: Temporality and the cultural legitimation of law', The Yale Law Journal 98, no. 8: 1631-1651.

Hein, S. F. (2013), 'Thinking and writing with ontological time', Qualitative Inquiry 19, no. 7: 493-501.

Kirsch, S. (2014), 'Imagining Corporate Personhood'. PoLAR: Political and Legal Anthropology Review 37, no. 2: 207-17. doi.org/10.1111/plar.12070.

Kirste, S. (2002), 'The temporality of law and the plurality of social times', in M. Troper and A. Verza (eds), Legal Philosophy: General Aspects. Concepts, Rights and Doctrines (Stuttgart: Steiner), 23-44.

Laclau, E. (2007), On Populist Reason (London: Verso).

Laidlaw, J. (2013), The Subject of Virtue: An Anthropology of Ethics and Freedom (Cambridge: Cambridge University Press).

Luhmann, N. (1981), Ausdifferenzierung des Rechts : Beiträge zur Rechtssoziologie und Rechtstheorie [Differentiation of law: Contributions to the sociology of law and legal theory] (Frankfurt a.M.: Suhrkamp).

McCulloch, J. and G. Tweedale (2008), Defending the Indefensible: The Global Asbestos Industry and Its Fight for Survival (Oxford: Oxford University Press).

Moore, S. F. (1972), 'Legal liabilities and evolutionary interpretation: Some aspects of strict liability, self-help, and collective responsibility', in Max Gluckman (ed), The Allocation of Responsibility. (Manchester: Manchester University Press), 51-108.

Munn, N. D. (1992), 'The cultural anthropology of time: A critical essay'. Annual Review of Anthropology 21: 93-123.

Rajak, D (2011), 'Theatres of virtue: Collaboration, consensus, and the social life of corporate social responsibility'. Focaal no. 60: 9-20. doi.org/10.3167/ fcl.2011.600102.

Ringel, F. (2016), 'Beyond temporality: Notes on the anthropology of time from a shrinking fieldsite', Anthropological Theory 16, no. 4: 390-412. doi:10.1177/1463499616659971.

Sangiovanni, A. (2013), 'Italian working men's masculinities in the latter half of the twentieth century', Clio: Women, Gender, History 38: 95-119. doi:10.4000/ cliowgh.295. 
Tweedale, G. and P. Hansen (2003), Magic Mineral to Killer Dust : Turner \& Newall and the Asbestos Hazard (Oxford: Oxford University Press).

Tronconi, F. (ed) (2015), Beppe Grillo's Five Star Movement: Organisation, Communication and Ideology (Farnham: Ashgate).

Veitch, S. (2007), Law and Irresponsibility: On the Legitimation of Human Suffering (Abingdon: Routledge-Cavendish).

Virta, R. L. (2006), Worldwide Asbestos Supply and Consumption Trends from 1900 through 2003 (Reston, VA: U.S. Geological Survey).

Welker, M. (2014), Enacting the Corporation: An American Mining Firm in Post-Authoritarian Indonesia (Berkeley: University of California Press).

White, M. J. (2006), 'Asbestos litigation: Procedural innovations and forum shopping', The Journal of Legal Studies 35, no. 2: 365-398. doi:10.1086/501096.

Zerilli, F. M. (2010), 'The Rule of Soft Law', Focaal no. 56: 3-18. doi:10.3167/ fcl.2010.560101.

Ziglioli, B. (2016), 'Sembrava Nevicasse' La Eternit di Casale Monferrato e la Fibronit di Broni: Due Comunità di fronte all'amianto (Milan: FrancoAngeli). 